Рогач I.M., Микита X.I., Палко А.I., Пішковці А.-М.M.

\title{
Структура захворюваності підлітків (15-17 років) м. Ужгорода та Закарпатської області в динаміці упродовж 2014-2018 років
}

\author{
ДВНЗ «Ужгородський національний університет», м. Ужгород, Україна \\ ivan.rogach@uzhnu.edu.ua,mikitachristina@gmail.com,palko.alice@gmail.com, anna-mariia.pishkovtsi@uzhnu.edu.ua
}

Рогач И.М., Микита Х.И., Палко А.И., Пішковці А.-М.М.

Структура заболеваемости подростков (15-17 лет)

г. Ужгорода и Закарпатской области

в динамике за 2014-2018 годы

ГВУЗ «Ужгородский национальный университет», г. Ужгород, Украина
Rohach I.M., Mykyta Ch.I., Palko A.I., Pishkovtsi A.-M.M.

Structure of the incidence of adolescents (15-17 years) of Uzhhorod and Transcarpathian region in dynamics during 2014-2018

SHEI “Uzhhorod National University”, Uzhhorod, Ukraine

\section{Вступ}

Серед найважливіших цінностей всіх народів особливе місце відводиться здоров'ю людей. Здоров'я нації визначається станом здоров'я іiі дітей. Численні дослідження показують, що порушення рівня здоров'я дорослих потрібно шукати в їхньому дитинстві. Здоров'я дітей $є$ інтегральним показником загального благополуччя суспільства [1-11].

В останні десятиліття спостерігається підвищення рівня захворюваності окремих органів і систем у всіх вікових категоріях дітей. Цьому сприяє зростання інтенсивного впливу на здоров'я дітей i підлітків екологічних та медико-соціальних факторів ризику, погіршення харчування, зниження ефективності профілактичних заходів, високий темп і ритм життя, модернізація навчального процесу, інформаційне перевантаження, збільшення гострої респіраторної захворюваності та відповідно пропусків занять, незадовільні санітарно-гігієнічні умови навчання, нераціональне навчальне навантаження, недосконалість медичного спостереження за дітьми, практичну відсутність системи психолого-педагогічної підтримки школярів при наявності значної кількості стресових ситуацій, значний дефіцит ефективних освітніх програм, спрямованих на формування у дітей культури здоров'я тощо [1,2,7,9-11].

Спостерігається зростання серед дітей та підлітків гострих і хронічних захворювань, синдрому дезадаптації, вроджених вад розвитку, морфофункціональних відхилень, розлади психіки та поведінки, зростає число інвалідів і зменшується кількість здорових дітей. Серед підлітків шкільного віку зростає поширеність усіх захворювань, але перші місця займають хвороби системи дихання, травлення, кістково-м'язової та сечостатевої системи, а також хвороби ока та придаткового апарату і нервово-психічні розлади. Особливо збільшується кількість захворювань у дітей, які навчаються у гімназіях, ліцеях, коледжах, що пов'язано 3 ускладненням навчальної програми, внаслідок чого діти перебувають у стресових умовах, у стані постійного напруження та навіть перенапруження, що $\epsilon$ вже преморбідним станом $[2,5,6,8,10]$.

Мета роботи - вивчити стан здоров'я підлітків м. Ужгорода та Закарпатської області в динаміці упродовж 2014-2018 років.

\section{Матеріали та методи}

Проаналізований статистичний матеріал Інформаційно-аналітичного центру Закарпатської області щодо захворюваності підлітків м. Ужгорода та Закарпатської області в динаміці упродовж 2014-2018 років. Отримані матеріали оброблені статистичним методом за допомогою комп’ютерної програми Microsoft Excel.

\section{Результати дослідження та їх обговорення}

На основі аналізу статистичного матеріалу щодо захворюваності підлітків м. Ужгорода в динаміці 20142018 років установлено, що найвища захворюваність спостерігається у 2017 році і складає 116,7\%; по області $1448,9 \%$; найнижча - у 2014 році $(83,2 \%$ ); по області $1357,3 \%$ (таблиця).

У структурі захворюваності серед підлітків м. Ужгорода в динаміці упродовж 2014-2018 років основне місце займають хвороби шкіри та підшкірної клітковини (25,32\%; 23,58\%, 25,86\%, 39,71\% і 41,01\% відповідно), у той же час як по області ці захворювання упродовж досліджуваних років займають значно нижчий відсоток 4,11\%; 4,89\%; 4,95\%; 5,94\% і 6,07\% відповідно (рис. 1). Серед цих захворювань найбільший відсоток складають у м. Ужгород упродовж досліджуваних років контактні дерматити $(25,54 \% ; 11,31 \% ; 7,07 \% ; 7,93 \%$ i $16,64 \%$ відповідно); по області - інфекції шкіри та підшкірної 
клітковини $(28,77 \% ; 27,98 \% ; 24,45 \% ; 21,24 \%$ i $24,22 \%$ відповідно).

Новоутворення серед підлітків м. Ужгорода упродовж досліджуваних 2014-2018 років посідають друге місце в структурі захворюваності, збільшуючись від
$12,94 \%$ у 2014 році до $31,08 \%$ у 2017 році, і знижуються більше, ніж у 4 рази у 2018 році (7,69\%). По області новоутворення серед підлітків за досліджувані роки займають незначний відсоток $(1,10 \% ; 1,15 \% ; 1,44 \% ; 1,50 \%$ і 1,01\% відповідно) (рис. 2).

\section{Таблиця. Захворюваність підлітків (15-17 років) м. Ужгорода та Закарпатської області} в динаміці упродовж 2014-2018 рр. (\%о)

\begin{tabular}{|l|c|c|c|c|c|}
\hline \begin{tabular}{|l|l|} 
Адміністративна \\
одиниця
\end{tabular} & $\mathbf{2 0 1 4}$ & $\mathbf{2 0 1 5}$ & $\mathbf{2 0 1 6}$ & $\mathbf{2 0 1 7}$ & $\mathbf{2 0 1 8}$ \\
\hline м. Ужгород & 83,21 & 101,14 & 97,94 & 116,73 & 112,05 \\
\hline Область & 1357,29 & 1389,43 & 1419,53 & 1448,99 & 1466,02 \\
\hline
\end{tabular}

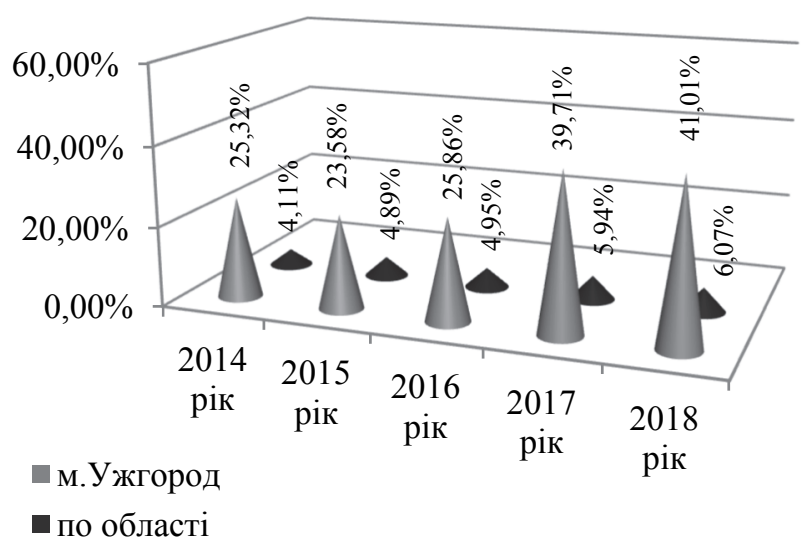

Рис. 1. Питома вага хвороб шкіри та підшкірної клітковини серед підлітків м. Ужгорода упродовж 2014-2018 pp. (\%)

Хвороби ока та придаткового апарату посідають значний відсоток у структурі захворюваності серед підлітків м. Ужгорода упродовж досліджуваних років, займаючи найбільший відсоток у 2014 році (12,65\%), незначно знижуються у динаміці наступних трьох років, дещо підвищуються у 2018 році до 11,88\%. По області вище приведені захворювання упродовж перших трьох досліджуваних років майже не змінюються, займаючи $7,85 \% ; 7,89 \%$ i 7,69\% відповідно, потім дещо підвищуються упродовж наступних 2017-2018 років до $8,09 \%$ і 8,15\% відповідно (рис. 3). У самій групі цих захворювань найбільший відсоток у м. Ужгород займають міопії, а саме, короткозорість упродовж досліджуваних років $(72,93 \% ; 76,88 \% ; 80,46 \% ; \quad 75,89 \%$ і $75,68 \%$ відповідно), і найчастіше ними хворіли дівчатка у 20142018 роках $(60,73 \% ; 57,02 \% ; 54,05 \% ; 53,88 \%$ і $53,39 \%$ відповідно); по області ці захворювання в динаміці досліджуваних років займають значно нижчий відсоток (33,01\%; 32,83\%; 34,31\%; 31,40\% і 33,89\% відповідно), і найчастіше ними хворіли також дівчатка $(55,79 \%$; 54,83\%; $56,06 \% ; 54,19 \%$ і 54,26\% відповідно).

Уроджені аномалії займають значну питому вагу в структурі захворюваності серед підлітків м. Ужгорода упродовж 2014-2018 років, знижуючись в динаміці від $12,40 \%$ у 2014 році до 7,21\% у 2017 році і знову підвищуються до 10,16\% у 2018 році; по області ці

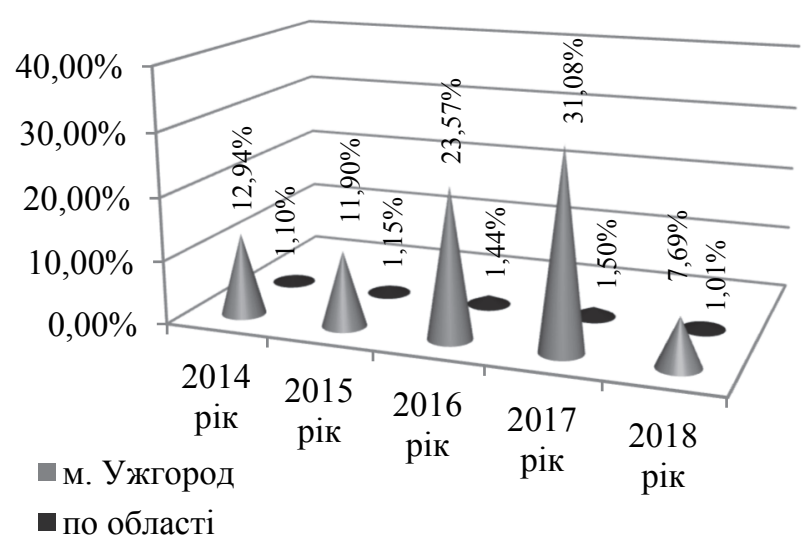

Рис. 2. Питома вага новоутворень серед підлітків м. Ужгорода упродовж 2014-2018 pp. (\%)

захворювання майже не змінюються в динаміці, складаючи незначний відсоток $(1,33 \% ; 1,33 \% ; 1,46 \%$; 1,43\% і 1,49\% відповідно) - рис. 4.

На високому рівні серед підлітків м. Ужгорода знаходяться хвороби ендокринної системи, розлади харчування, порушення обміну речовин, які мають тенденцію до збільшення з 11,95\% у 2014 році до 17,94\% у 2015 році, а потім знижуються до 12,64\% у 2018 році. По області ці захворювання знаходяться на досить високому рівні і незначно змінюються в динаміці досліджуваних років $(13,17 \% ; 14,15 \% ; 13,51 \% ; 13,83 \%$ і $14,19 \%$ відповідно) - рис. 5. Найбільш поширеними серед цих захворювань $є$ дифузний зоб I ступеня як у м. Ужгород (12,27\%; 71,93\%; 51,87\%; 58,81\% і 53,37\% відповідно), так і по області упродовж $2014-2018$ років $(57,05 \% ; 61,30 \%$; $56,86 \% ; 56,77 \%$ і 54,06\% відповідно) та ожиріння (20,52\%; $16,67 \% ; 22,57 \% ; 21,55 \%$ і 24,47\% відповідно у м. Ужгород та по області $14,49 \% ; 14,02 \% ; 14,36 \% ; 14,88 \%$ і $15,57 \%$ відповідно).

На досить високому рівні упродовж 2014-2016 років знаходяться і хвороби системи кровообігу серед підлітків м. Ужгорода (10,58\%; 9,93\% і 10,21\% відповідно), а потім різко знижуються у 2017-2018 роках до $3,40 \%$ i $3,56 \%$ відповідно. По області ці захворювання займають значно нижчий відсоток упродовж 2014-2018 років (3,41\%; 3,42\%; 3,26\%; 2,89\% і 2,79\% відповідно) - рис. 6. 


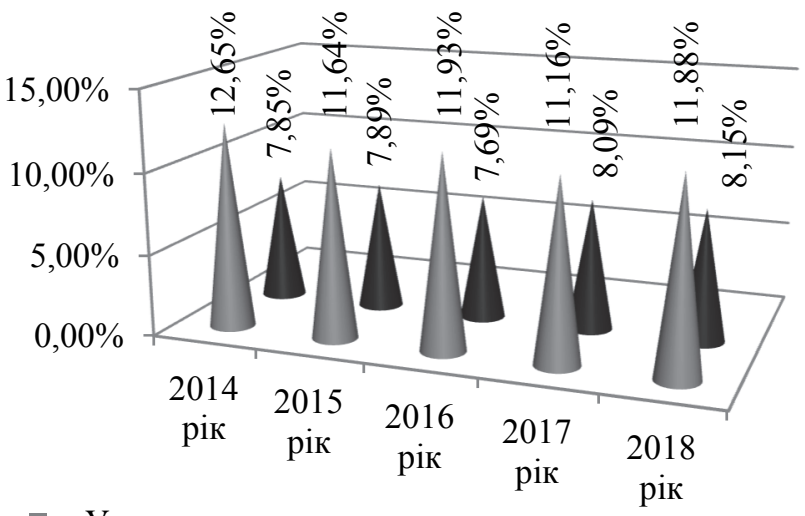

м.Ужгород

п по області

Рис. 3. Питома вага хвороб ока та придаткового апарату серед підлітків м. Ужгорода упродовж 2014-2018 pр. (\%)

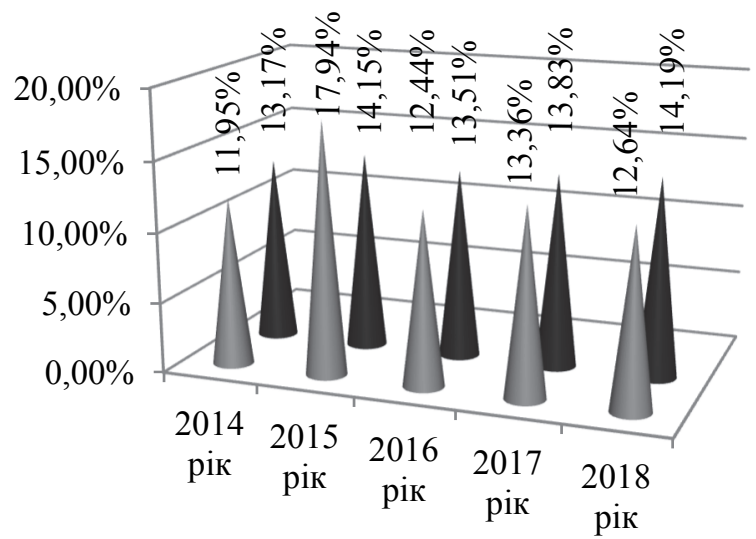

м.Ужгород

по області

Рис. 5. Питома вага хвороб ендокринної системи, розладів харчування та порушення обміну серед підлітків м. Ужгорода упродовж 2014-2018 pp. (\%)

Наступне місце у структурі захворюваності серед підлітків м. Ужгорода упродовж 2014-2018 років займають розлади психіки і поведінки, які знижуються від 9,51\% у 2014 році до 7,87\% у 2016 році, а потім знову підвищуються до $10,39 \%$ у 2018 році; по області ці захворювання займають незначний відсоток упродовж досліджуваних років $(2,53 \% ; 2,44 \% ; 2,46 \% ; 2,03 \%$ і 1,80\% відповідно) - рис. 7.

Значний відсоток у структурі захворюваності серед підлітків м. Ужгород посідають хвороби органів травлення, які в динаміці досліджуваних років знижуються від 8,69\% у 2014 році до 7,24\% у 2015 році, а потім з 2016 року підвищуються від 8,59\% до 9,74\% у 2018 році. По області хвороби органів травлення займають дещо вищий відсоток у 2014 році (8,91\%), а потім незначно знижуються упродовж наступних $2015-2018$ років $(8,23 \%$; $8,37 \% ; 8,56$ і 8,66\% відповідно) - рис. 8 .

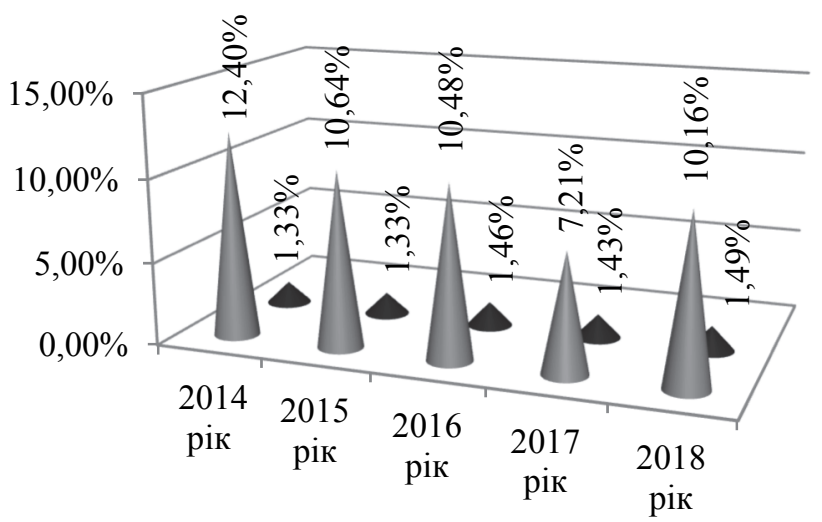

м. Ужгород

п по області

Рис. 4. Питома вага уроджених аномалій серед підлітків м. Ужгорода упродовж 2014-2018 pp. (\%)

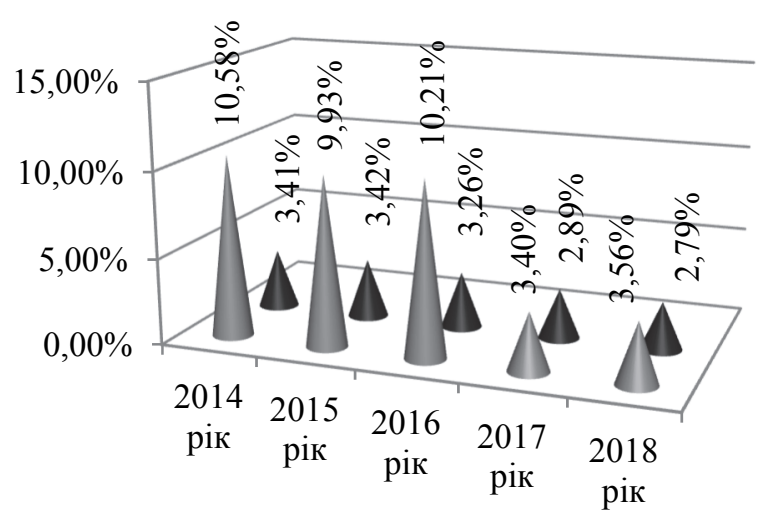

м.Ужгород

п по області

Рис. 6. Питома вага хвороб системи кровообігу серед підлітків м. Ужгорода упродовж 2014-2018 pp. (\%)

Найбільший відсоток цієї групи у м. Ужгород за досліджуваний період складають холецистит і холангіт та гастрит і дуоденіт (10,71\%; 9,45\%; 8,39\%; 13,50\% і 12,73\% відповідно та 9,80\%; 3,80\%; 5,76\%; 6,43\% і 6,61\% відповідно) i незначний відсоток упродовж 20142018 років займають виразкова хвороба шлунку та 12-и палої кишки i хронічні гепатити. По області холецистит і холангіт упродовж 2014-2018 років займає значно нижчий відсоток $(7,33 \% ; 6,27 \% ; 5,98 \% ; 5,16 \%$ і 5,11\% відповідно), а гастрит і дуоденіт, навпаки, в 3-4 рази перевищує показник м. Ужгорода $(26,18 \% ; 26,65 \%$; 24,45\%; 23,14\% і 25,75\% відповідно).

Хвороби нервової системи, інфекційні та паразитарні захворювання посідають наступне місце в структурі захворювань серед підлітків м. Ужгорода упродовж 2014-2018 років. У динаміці досліджуваних років хвороби нервової системи дещо знижуються від 
$7,23 \%$ у 2014 році до 6,36\% у 2018 році, у той же час як інфекційні та паразитарні захворювання в динаміці мають тенденцію до збільшення від 7,65\% у 2014 році до 10,34\% у 2018 році. По області хвороби нервової системи,

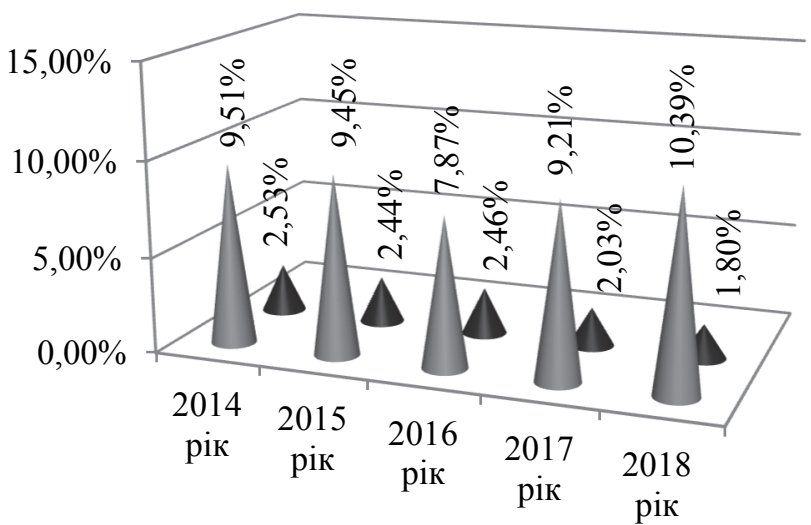

м. Ужгород

п по області

Рис. 7. Питома вага розладів психіки і поведінки серед підлітків м. Ужгорода упродовж 2014-2018 pp. (\%)

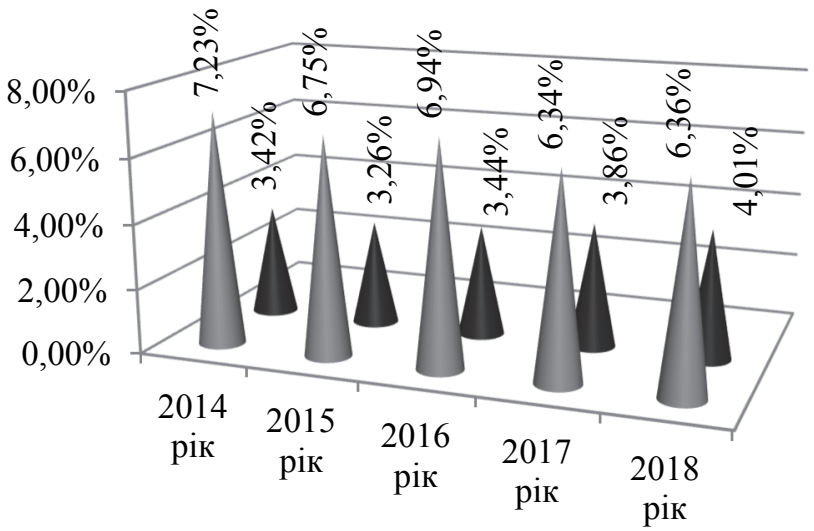

м. Ужгород

п по області

Рис. 9. Питома вага хвороб нервової системи серед підлітків м. Ужгорода упродовж 2014-2018 pp. (\%)

Досить високу питому вагу у структурі захворюваності серед підлітків упродовж досліджуваних років складають хвороби кістково-м'язової та сполучної тканини і сечостатевої системи. Хвороби кістковом'язової системи серед підлітків м. Ужгорода дещо знижуються від 6,86\% у 2014 році до 5,78\% у 2016 році, незначно підвищуються у 2017 році до 6, 38\%, а потім знижуються до 6,03\%; по області ці захворювання майже не змінюються упродовж досліджуваних років $(6,34 \%$; 6,38\%; 6,18\%; 6,14\% і 6,35\% відповідно) - рис. 11 .

Навпаки, хвороби сечостатевої системи серед підлітків м. Ужгорода дещо підвищуються у динаміці досліджуваних років від $6,81 \%$ у 2014 році до 7,94\% у інфекційні та паразитарні захворювання займають значно нижчий відсоток у структурі захворюваності серед підлітків упродовж досліджуваних років, особливо інфекційні та паразитарні захворювання (рис. 9, 10).

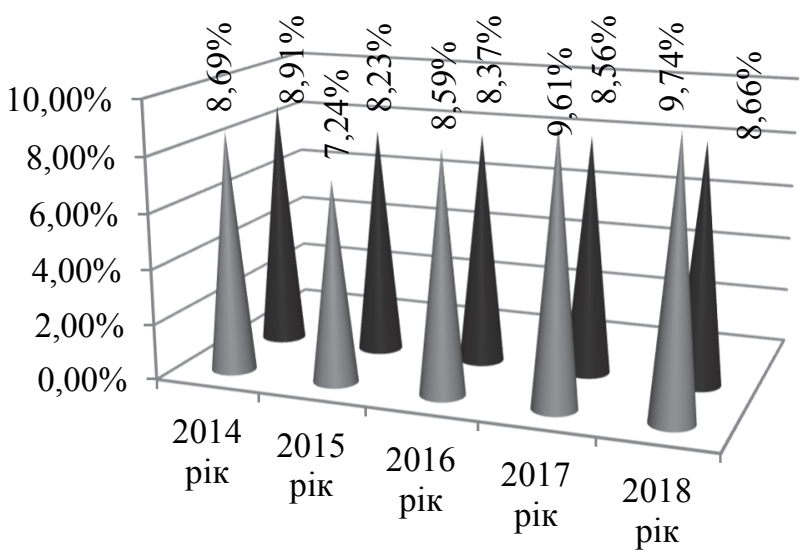

м.Ужгород

по області

Рис. 8. Питома вага хвороб органів травлення серед підлітків м. Ужгорода упродовж 2014-2018 pp. (\%)

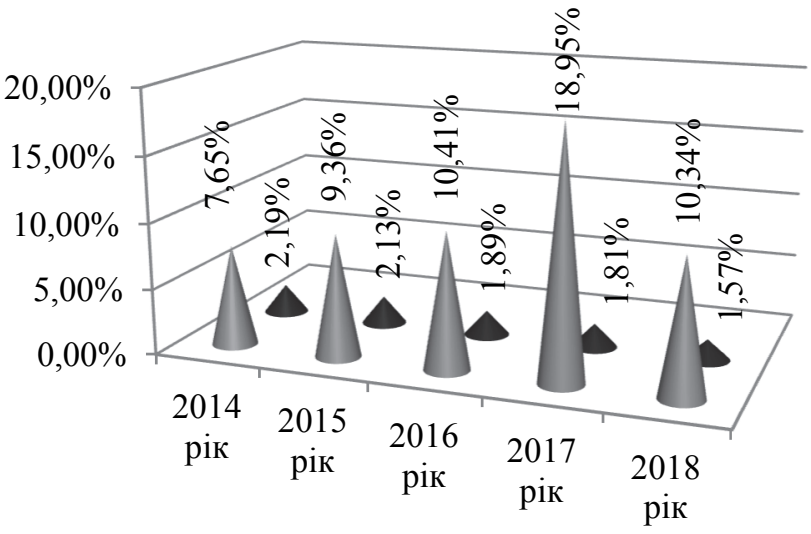

м. Ужгород

п по області

Рис. 10. Питома вага інфекційних та паразитарних захворювань серед підлітків м. Ужгорода упродовж 2014-2018 pp. (\%)

2017 році, незначно знижуючись у 2018 році (7,68\%), у той же час як по області вони займають незначний відсоток (рис. 12).

Значно нижчий відсоток у структурі захворюваності серед підлітків м. Ужгорода займають хвороби органів дихання, травми, отруєння та деякі інші наслідки дії зовнішніх причин, а також хвороби вуха та соскоподібного відростка у динаміці досліджуваних років. Хвороби органів дихання закономірно збільшуються у динаміці від 4,99\% у 2014 році до 10,36\% - у 2018 році. По області ці захворювання за всі досліджувані роки займають перше місце серед всіх захворювань і майже не змінюються в динаміці $(32,26 \% ; 30,92 \% ; 32,43 \% ; 30,96 \%$ i 
31,23\% відповідно) - рис. 13. Найчастіше ними хворіли в 2014-2018 роках у м. Ужгород юнаки (52,51\%; 53,09\%;50,95\%; 50,69\% і 58,96\% відповідно) i, навпаки, по області у 2014 році - дівчатка $(51,32 \%)$ і значно менше хворіли юнаки упродовж 2014-2015 років (48,68\% і 47,59\% відповідно), дещо підвищуються у 2016 році до 51,27\%, а потім знову знижуються у 2017-2018 роках $(47,97 \%$ i 49,22\% відповідно)

Серед цих захворювань найбільший відсоток серед підлітків по області у 2014 році складають фарингіт та гострий тонзиліт $(9,48 \%)$, які незначно знижуються у 2015 2016 роках (8,94\% і 8,89\% відповідно), а потім поступово збільшуються у 2017-2018 роках до10,29\% і 10,84\% відповідно, у той же час як у м. Ужгород упродовж досліджуваних років ці захворювання становили значно нижчий відсоток, займаючи 2,29\%; 4,19\%; $1,39 \% ; 5,06 \%$ і $6,09 \%$ відповідно. Значний відсоток у структурі захворюваності органів дихання займають хвороби

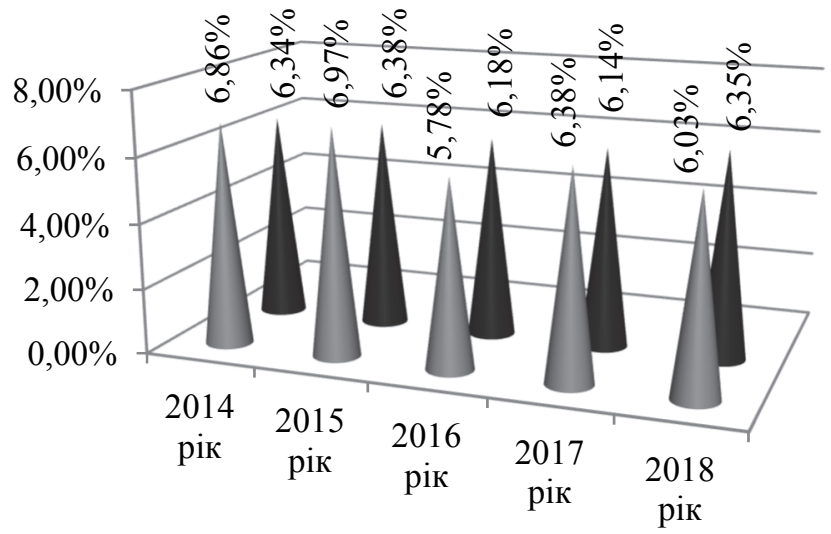

$$
\text { м.Ужгород }
$$$$
\text { по області }
$$

Рис. 11. Питома вага хвороб кістково-м'язової системи та сполучної тканини серед підлітків м. Ужгорода упродовж 2014-2018 pp. (\%)

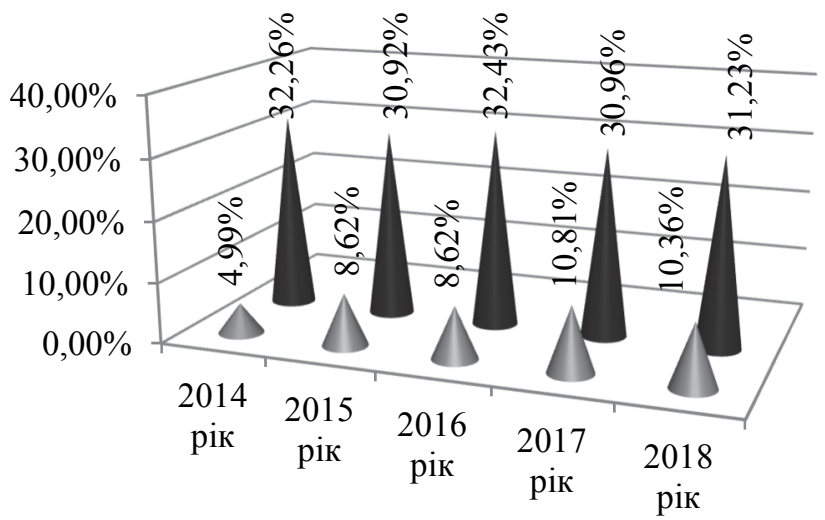

м.Ужгород

п по області

Рис. 13. Питома вага хвороб органів дихання серед підлітків м. Ужгорода упродовж 2014-2018 pp. (\%) мигдалин та аденоїдів у м. Ужгород упродовж 2014-2018 років - 10,96\%; 10,97\%; 7,68\%; 7,95\% і 9,32\% відповідно; по області ці захворювання займають дещо нижчий відсоток упродовж досліджуваних років $(6,89 \% ; 7,73 \%$; $7,37 \%$; 6,96\% i 7,52\% відповідно). Ларингіт і трахеїт упродовж 2014-2018 років по області займає значний відсоток, а саме, 5,82\%; 6,49\%; 5,96\%; 6,73\%;6,77\% відповідно, у той же час як у м. Ужгород цими хворобами підлітки хворіли лише у 2016-2018 роках, складаючи незначний відсоток $(0,35 \% ; 0,58 \%$ і $1,54 \%$ відповідно). Найчастіше цими захворюваннями упродовж досліджуваних років хворіли дівчатка, як у м. Ужгород, так і по області.

Травми, отруєння та деякі інші наслідки дії зовнішніх причин серед підлітків як у м. Ужгород, так і по області майже не змінюються у динаміці упродовж 20142018 років $(4,35 \% ; 3,96 \% ; 3,70 \% ; 3,09 \%$ і 3,03\% відповідно та 5,32\%; 5,40\%; 5,36\%; 5,38\% і 5,03\% відповідно) - рис. 14.

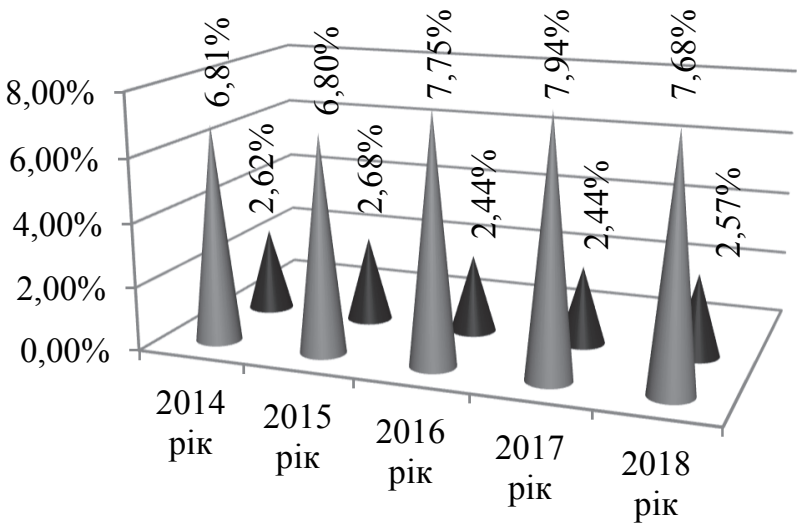

$$
\begin{aligned}
& \text { м. Ужгород } \\
& \text { по області }
\end{aligned}
$$

Рис. 12. Питома вага хвороб сечостатевої системи серед підлітків м. Ужгорода упродовж 2014-2018 pp. (\%)

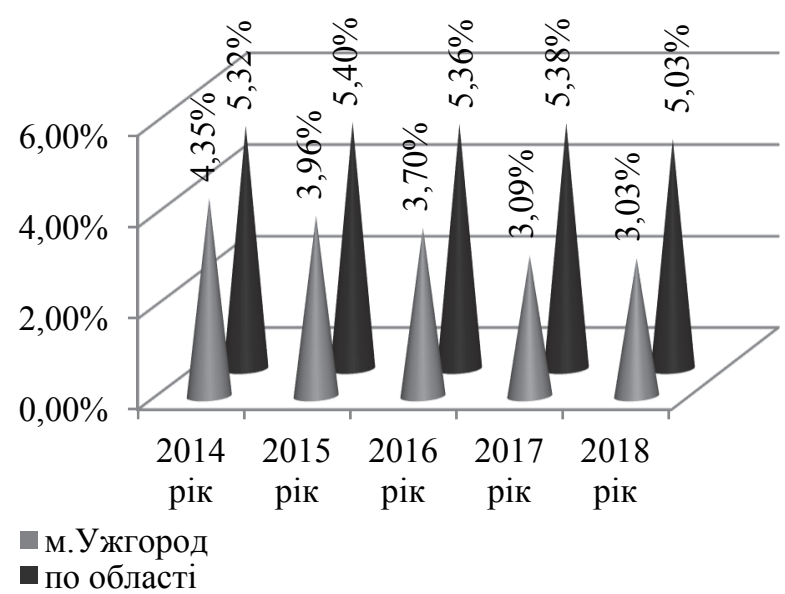

Рис. 14. Питома вага травм, отруєнь та деяких інших наслідків дії зовнішніх причин серед підлітків м. Ужгорода упродовж 2014-2018 pp. (\%) 
Хвороби вуха та соскоподібного відростка серед підлітків м. Ужгорода у динаміці дещо знижуються від $3,65 \%$ у 2014 році до $2,96 \%$ у 2015 році, потім підвищуються до 5,06\% у 2017 році; по області ці захворювання майже не змінюються упродовж досліджуваних років і займають значно нижчий відсоток.

I останне місце в структурі захворюваності серед підлітків займають хвороби крові та кровотворних органів, вони складають незначний відсоток як у м. Ужгород, так і по області упродовж 2014-2018 років $(1,63 \% ; 1,99 \% ; 1,85 \% ; 1,95 \%$ i 2,68\% відповідно та $2,19 \% ; 2,21 \% ; 2,17 \% ; 2,23 \%$ і 2,35\% відповідно).

Перспективи подальших досліджень спрямовані на подальше вивчення стану здоров'я і фізичного розвитку дитячого населення м. Ужгорода та Закарпатської області.

\section{Висновки}

Найвища захворюваність серед підлітків м. Ужгорода відмічається у 2017 році (116,73\%), по області у 2018 році (1466,02\%о), а найнижча - у 2014 році як у м. Ужгород, так і по області $(83,21 \%$ і $1357,29 \%$ відповідно). У структурі захворюваності серед підлітків м. Ужгород й області у динаміці упродовж 2014-2018 років найбільшу питому вагу складають хвороби шкіри та підшкірної клітковини $(25,32 \% ; 23,58 \%, 25,86 \%, 39,71 \%$ і $41,01 \%$ відповідно), у той же час як по області ці захворювання упродовж досліджуваних років займають значно нижчий відсоток $(4,11 \% ; 4,89 \% ; 4,95 \% ; 5,94 \%$ i $6,07 \%$ відповідно), а найнижчу в м. Ужгород - хвороби крові та кровотворних органів $(1,63 \% ; 1,99 \% ; 1,85 \%$; $1,95 \%$ і $2,68 \%$ відповідно та по області - 2,19\%; $2,21 \%$; $2,17 \% ; 2,23 \%$ і 2,35\% відповідно). Для покращення стану здоров'я підлітків необхідно широко пропагувати здоровий спосіб життя, організацію і проведення спортивно-оздоровчих заходів, відновлення у загальноосвітніх школах оборонно-фізкультурної підготовки юнаків і дівчат, які спрямовані на тренуванні спеціальних якостей, розвитку фізичної і психоемоційної витривалості та впровадження нових оздоровчих технологій, підвищення рівня медичних знань тощо.

\section{Література}

1. Басанець Л.М. Вплив мікросоціального середовища на фізичний розвиток і стан здоров'я дітей а підлітків / Л.М.Басанець, О.І.Іванова // Довкілля та здоров’я. - 2010. - №1(52). - С. 52-55.

2. Динаміка стану здоров'я дитячого населення за останні роки реформування медичної сфери України / О.П.Івахно, І.П.Козярін, В.В.Чорна, В.М.Махнюк // Зб. наук. праць співробітників НМАПО імені П.Л.Шупика. 2015. - Вип. 24. - Кн. 3. - С. $447-454$.

3. Значение здоровья подростков в формировании их гармоничного здоровья / А.А.Баранов, В.Р.Кучма, П.М.Сухарева, И.К.Рапопорт // Гигиена и санитария. - 2015. - № 6. - С. 58-62.

4. Кучма В.Р. Охрана здоровья детей и подростков в национальной стратегии действий в интересах детей на 2012-2017 год / В.Р.Кучма // Гигиена и санитария. - 2013. - № 6. - С.26-30.

5. Микита Х.І. Оцінка стану здоров’я дітей шкільного віку м. Ужгород у динаміці впродовж 2012-2016 років / Х.І.Микита, I.М.Рогач // Проблеми клінічної педіатрії. - 2017. - №1-2 (35-36). - С. 56-62.

6. Микита Х.І. Стан здоров’я дітей шкільного віку гірських районів Закарпатської області в динаміці впродовж 2013-2017 років / X.І.Микита, I.М.Рогач // Проблеми клінічної педіатрії. - 2018. - №2-3 (40-41). - С. 57-62.

7. Наукові принципи психогігієнічної діагностики стану здоров'я дітей, підлітків та молоді / І.В.Сергета, О.Ю.Браткова, О.П.Мостова, О.Ю.Панчук, О.Б.Дударенко // Довкілля та здоров’я. - 2012. - № 4(63). - С. 21-25.

8. Пономаренко Н.П. Динаміка захворюваності дитячого населення Чернігівщини / Н.П.Пономаренко // Гігієна населених місць. - 2012. - Вип. 60. - С.93 - 98.

9. Сидоренко Т.П. Ризик зниження рівня соматичного здоров'я здорових підлітків під впливом різних чинників / Т.П.Сидоренко, О.В.Бердник // Довкілля та здоров'я. - 2011. - № 2(57). - С. 71 - 74.

10. Фера О.В. Особливості стану здоров'я та фізичного розвитку допризовників віком 17 років (1991 р.н.) низинних районів ендемічного регіону (на прикладі Закарпатської області) за 2008 рік / О.В.Фера, Х.І.Микита, В.Г.Пирогова // Довкілля та здоров'я. - 2009. - № 3(50). - С. 76 - 80.

11. Щудро С.А. Регіональні аспекти впливу екологічних факторів на захворюваність підлітків / С.А.Щудро // Медичні перспективи. - 2008. - Т. 12. - № 4. - С. 115 - 119.

\section{References}

1. Basanets L. M., Ivanova O. I. Vplyv mikrosotsialnoho seredovyshcha na fizychnyi rozvytok i stan zdorovia ditei a pidlitkiv [Influence of microsocial environment on physical development and health status of children and adolescents]. Environment and health. 2010; 1(52): 52-55.

2. Ivakhno O. P., Kozyaryn I. P., Chorna V. V., Makhnyuk V. M. Dynamika stanu zdorovia dytiachoho naselennia za ostanni roky reformuvannia medychnoi sfery Ukrainy [Dynamics of the health status of the infant population in recent years of reforming the medical sphere of Ukraine]. Coll. of sciences. works of P. L. Shupyk NMAPO employees. 2015; Vip.24. Book $3: 447-454$ 
3. Baranov A. A., Kuchma V. R., Sukhareva P. M., Rapoport I. K. Znachenye zdorovia podrostkov v formyrovanyy ykh harmonychnoho zdorovia [The importance of adolescents' health in the formation of their harmonious health]. Hygiene and sanitation. 2015; 6:58-62.

4. Kuchma V. R. Okhrana zdorovia detei y podrostkov v natsyonalnoi stratehyy deistvyi v ynteresakh detei na 20122017 hod [Protecting the health of children and adolescents in the national strategy for action interests of children for 20122017]. Hygiene and sanitation. 2013; 6: 26-30.

5. Mykita Kh. I., Rogach I. M. Otsinka stanu zdorovia ditei shkilnoho viku m. Uzhhorod u dynamitsi vprodovzh $2012-$ 2016 rokiv [Assessment of health status of Uzhgorod school children in dynamics during 2012-2016]. Problems of clinical pediatrics. 2017; 1-2 (35-36):56-62.

6. Mykita Kh. I., Rogach I. M. Stan zdorovia ditei shkilnoho viku hirskykh raioniv Zakarpatskoi oblasti v dynamitsi vprodovzh 2013-2017 rokiv [Health status of school-age children in mountainous regions of Transcarpathian region in the dynamics during 2013-2017]. Problems of clinical pediatrics. 2018; 2-3 (40-41): 57 -62.

7. Sergeta I. V., Bratkov O. J., Mostova O. P., Panchuk O. Y., Dudaryenko O. B. Naukovi pryntsypy psykhohihiienichnoi diahnostyky stanu zdorovia ditei, pidlitkiv ta molodi [Scientific principles of psychohygienic diagnostics of health status of children, adolescents and young people]. Environment and health. 2012; 4 (63): 21 - 25.

8. Ponomarenko N. P. Dynamika zakhvoriuvanosti dytiachoho naselennia Chernihivshchyny [Dynamics of morbidity of the pediatric population of Chernihiv region]. Hygiene of settlements. 2012; Vip. 60: 93 - 98.

9. Sidorenko T. P., Berdnyk O. V. Ryzyk znyzhennia rivnia somatychnoho zdorovia zdorovykh pidlitkiv pid vplyvom riznykh chynnykiv [The risk of somatic health decline in healthy adolescents under the influence of various factors]. Environment and health. 2011; 2 (57): $71-74$.

10. Fera O. V., Mykyta Kh. I., Pirogov V. G. Osoblyvosti stanu zdorovia ta fizychnoho rozvytku dopryzovnykiv vikom 17 rokiv (1991 r.n.) nyzynnykh raioniv endemichnoho rehionu (na prykladi Zakarpatskoi oblasti) za 2008 rik [Peculiarities of health and physical development of pre-conscripts at the age of 17 (1991) of lowland areas of the endemic region (on the example of Transcarpathian region) for 2008]. Environment and health. 2009; 3 (50): 76 - 80.

11. Generously S.A. Rehionalni aspekty vplyvu ekolohichnykh faktoriv na zakhvoriuvanist pidlitkiv [Regional aspects of the influence of environmental factors on adolescent morbidity]. Medical perspectives. 2008; T. 12. 4: 115 - 119.

Дата надходження рукопису до редакції: 24.02.2020 p.

Мета - вивчити стан здоров’я підлітків (15-17 років) м. Ужгорода та Закарпатської області в динаміці упродовж 2014-2018 років.

Матеріали та методи. Проаналізований статистичний матеріал Інформаційно-аналітичного центру Закарпатської області щодо захворюваності підлітків м. Ужгорода та Закарпатської області в динаміці упродовж 20142018 років. Отримані матеріали оброблені статистичним методом за допомогою комп'ютерної програми Microsoft Excel.

Результати. На основі аналізу статистичного матеріалу щодо захворюваності підлітків м. Ужгорода та Закарпатської області в динаміці 2014-2018 років установлено, що найвища захворюваність спостерігається у 2017 році і складає 116,7\%; по області - 1448,9\%о; найнижча - у 2014 році (83,2\%о); по області - 1357,3\%о. У структурі захворюваності серед підлітків м. Ужгорода й області у динаміці упродовж 2014-2018 років найбільшу питому вагу складають хвороби шкіри та підшкірної клітковини (25,32\%; 23,58\%, 25,86\%, 39,71\% і 41,01\% відповідно), у той же час як по області ці захворювання упродовж досліджуваних років займають значно нижчий відсоток $(4,11 \% ; 4,89 \% ; 4,95 \%$; 5,94\% і 6,07\% відповідно), а найнижчу в м. Ужгород - хвороби крові та кровотворних органів (1,63\%; 1,99\%; 1,85\%; 1,95\% і 2,68\% відповідно; по області - 2,19\%; 2,21\%; 2,17\%; 2,23\% і 2,35\% відповідно).

Висновки. Найвища захворюваність серед підлітків м. Ужгорода відмічається у 2017 році (116,73\%о), по області у 2018 році (1466,02\%о), а найнижча - у 2014 році як у м. Ужгород, так і по області (83,21\%о і 1357,29\%о відповідно). У структурі захворюваності серед підлітків м. Ужгорода й області у динаміці упродовж 2014-2018 років найбільшу питому вагу складають хвороби шкіри та підшкірної клітковини $(25,32 \% ; 23,58 \%, 25,86 \%, 39,71 \%$ і 41,01\% відповідно), у той же час як по області ці захворювання упродовж досліджуваних років займають значно нижчий відсоток (4,11\%; 4,89\%; 4,95\%; 5,94\% і 6,07\% відповідно), а найнижчу в м. Ужгород - хвороби крові та кровотворних органів (1,63\%; 1,99\%; $1,85 \% ; 1,95 \%$ і 2,68\% відповідно; по області - 2,19\%; 2,21\%; 2,17\%; 2,23\% і 2,35\% відповідно). Для покращення стану здоров'я підлітків необхідно широко пропагувати здоровий спосіб життя, організацію і проведення спортивнооздоровчих і корекційних заходів, відновлення у загальноосвітніх школах оборонно-фізкультурної підготовки юнаків і дівчат, які спрямовані на тренуванні спеціальних якостей, розвитку фізичної і психоемоційної витривалості та впровадження нових оздоровчих технологій, підвищення рівня медичних знань тощо.

Ключові слова: здоров'я, підлітки, захворюваність, профілактичні заходи. 
Цель - изучить состояние здоровья подростков (15-17 лет) г. Ужгорода и Закарпатской области в динамике за 2014-2018 годы.

Материалы и методы. Проанализирован статистический материал Информационно-аналитического центра Закарпатской области по заболеваемости подростков г. Ужгорода и Закарпатской области в динамике за 20142018 годы. Полученные материалы обработаны статистическим методом с помощью компьютерной программы Microsoft Excel.

Результаты. На основании анализа статистического материала по заболеваемости подростков г. Ужгорода и Закарпатской области в динамике за 2014-2018 годы установлено, что наибольшая заболеваемость наблюдается в 2017 году и составляет 116,7\%; по области - 1448,9\%; наименьшая - у 2014 году (83,2\%о); по области - 1357,3\%о. В структуре заболеваемости среди подростков г. Ужгорода и области в динамике за 2014-2018 годы наибольший удельный вес составляють болезни кожи и подкожной клетчатки $(25,32 \% ; 23,58 \%, 25,86 \%, 39,71 \%$ и 41,01\% соответственно), в то же время как по области эти заболевания за исследуемые годы занимают значительно меньший процент $(4,11 \% ; 4,89 \% ; 4,95 \% ; 5,94 \%$ и $6,07 \%$ соответственно), а наименьший в г. Ужгороде - болезни крови и кроветворных органов $(1,63 \% ; 1,99 \% ; 1,85 \% ; 1,95 \%$ и $2,68 \%$ соответственно; по области $-2,19 \% ; 2,21 \% ; 2,17 \% ; 2,23 \%$ и $2,35 \%$ соответственно).

Выводы. Наибольшая заболеваемость среди подростков г. Ужгорода наблюдается в 2017 году (116,73\%o), по области в 2018 году (1466,02\%о), а наименьшая - в 2014 году как в г. Ужгороде, так и по области (83,21\%о и 1357,29\%о соответственно). В структуре заболеваемости среди подростков г. Ужгорода и области в динамике за 2014-2018 годы наибольший удельный вес составляют болезни кожи и подкожной клетчатки $(23,58 \%, 25,86 \%, 39,71 \%$ и 41,01\% соответственно), в то же время как по области эти заболевания за исследуемые годы занимают значительно меньший процент $(4,11 \% ; 4,89 \% ; 4,95 \% ; 5,94 \%$ и 6,07\% соответственно), а наименьший в г. Ужгороде - болезни крови и кроветворных органов $(1,63 \% ; 1,99 \% ; 1,85 \% ; 1,95 \%$ и $2,68 \%$ соответственно; по области - 2,19\%; 2,21\%; 2,17\%; $2,23 \%$ и 2,35\% соответственно). Для улучшения состояния здоровья подростков необходимо широко пропагандировать здоровый образ жизни, организацию и проведение спортивно-оздоровительных и корекционных мероприятий, восстановление в общеобразовательных школах оборонно-физкультурной подготовки юношей и девушек, которые направлены на тренировку специальных качеств, розвитие физической и психоэмоциальной стойкости и внедрение новых оздоровительных технологий, повышение уровня медицинских знаний и т.д.

Ключевые слова: здоровье, подростки, заболеваемость, профилактические мероприятия.

\begin{abstract}
Aim of study - to study adolescents' health status at age of 15-17 y.o. in Uzhhorod and Transcarpathian region in the dynamics during 2014-2018.

Materials and methods. The statistical material of the Transcarpathian Information and Analytical Center on the incidence of adolescents in Uzhhorod and the Transcarpathian region in the dynamics during 2014-2018 has been analyzed. Obtained materials were statistically processed using the Microsoft Excel.

Results. Based on the analysis of statistical material on the incidence of adolescents in Uzhhorod in the 2014-2018 dynamics it was established that the highest incidence was observed in 2017 and it is $116,7 \%$; by the region - $1448,9 \%$; the lowest incidence was observed in 2014 (83,2\%); by the region - 1357,3\%. In the structure of morbidity among adolescents of Uzhhorod and the region in the dynamics during 2014-2018 years the most common were diseases of the skin and subcutaneous tissue, $(25,32 \% ; 23,58 \%, 25,86 \%, 39,71 \%$ and $41,01 \%$ accordingly $)$, while by the region these diseases during the studied years occupy much lower percentage $-4,11 \% ; 4,89 \% ; 4,95 \% ; 5,94 \%$ and $6,07 \%$ respectively, while the lowest percentage in Uzhhorod belongs to blood and hematopoietic diseases $(1,63 \% ; 1,99 \% ; 1,85 \% ; 1,95 \%$ and $2,68 \%$ respectively), by the region $-2,19 \%$; $2,21 \% ; 2,17 \% ; 2,23 \%$ and $2,35 \%$ respectively.
\end{abstract}

Conclusions. The highest incidence among adolescents in Uzhhorod is recorded in 2017 (116.73\%o), by the region in 2018 (1466.02\%o), and the lowest in 2014 in both - Uzhhorod and the region (83.21 13 and 1357.29\%o respectively). In the structure of morbidity among adolescents of Uzhgorod and the region in dynamics during 2014-2018 years the most common are the diseases of skin and subcutaneous tissue, $(25,32 \% ; 23.58 \%, 25.86 \%, 39.71 \%$ and $41.01 \%$ respectively), while in the region these diseases during the studied years occupy a much lower percentage $-4.11 \% ; 4.89 \% ; 4.95 \% ; 5.94 \%$ and $6.07 \%$ respectively, while the lowest percentage in Uzhhorod belong to blood and hematopoietic diseases $(1.63 \% ; 1.99 \% ; 1.85 \% ; 1.95 \%$ and $2.68 \%$ respectively), by region $-2,19 \% ; 2,21 \% ; 2,17 \% ; 2,23 \%$ and $2,35 \%$ respectively. To improve the health of adolescents, it is necessary to widely promote healthy lifestyle, organization and holding of sports-improving and corrective measures, restoration in the secondary schools of defense and physical training of young men and girls at training of special qualities, development of physical and psychoemotional endurance introduction of new wellness technologies, improvement of medical knowledge level, etc.

Key words: health, adolescents, morbidity, preventive measures.

Конфлікт інтересів: відсутній.

Conflicts of interest: authors have no conflicts of interest to declare. 


\section{Відомості про авторів}

Рогач Іван Михайлович - д.мед.н., завідувач кафедри соціальної медицини та гігієни ДВНЗ «Ужгородський національний університет»; пл. Народна 3, м. Ужгород, Закарпатська обл., 88000, Україна.

+380 (95) 403-87-56, ivan.rogach@uzhnu.edu.ua.

Микита Христина Іванівна - к.біол.н., доцент кафедри соціальної медицини та гігієни ДВНЗ «Ужгородський національний університет»; пл. Народна 3, м. Ужгород, Закарпатська обл., 88000, Україна.

+380 (99) 008-73-72, mikitachristina@gmail.com.

Палко Аліса Іванівна - к.біол.н., доцент кафедри соціальної медицини та гігієни ДВНЗ «Ужгородський національний університет»; пл. Народна 3, м. Ужгород, Закарпатська обл., 88000, Україна.

+380 (66) 635-21-96, palko.alice@gmail.com.

Пішковці Анна-Марія Михайлівна - аспірант, асистент кафедри гігієни та екології ДВНЗ «Ужгородський національний університет»; пл. Народна 3, м. Ужгород, Закарпатська обл., 88000, Україна.

+380 (96) 230-02-30, anna-mariia.pishkovtsi@uzhnu.edu.ua. 